\title{
ON THE FREQUENCY OF INTERIOR COURNOT-NASH EQUILIBRIA IN A PUBLIC GOOD ECONOMY
}

\author{
WOLFGANG BUCHHOLZ \\ RICHARD CORNES \\ WOLFGANG PETERS
}

CESIFO WORKING PAPER NO. 982

CATEgory 1: Public FinAnCE

JULY 2003

\footnotetext{
An electronic version of the paper may be downloaded

- from the SSRN website: www.SSRN.com

- from the CESifo website: www.CESifo.de
} 


\title{
ON THE FREQUENCY OF INTERIOR COURNOT-NASH EQUILIBRIA IN A PUBLIC GOOD ECONOMY
}

\begin{abstract}
In a public good economy the distribution of initial income is an important determinant of how many individuals contribute to the public good. For the case when all individuals have identical preferences in this paper a simple formula is derived that describes the proportion of all income distributions for which an interior Cournot-Nash equilibrium will result in which every agent makes a strictly positive contribution to the public good. This formula is then applied to a standard Cobb-Douglas utility function showing that the likelihood of interior Cournot-Nash equilibria falls dramatically when the number of individuals is increased. The implications this result might have for the significance of Shibata-Warr neutrality are finally discussed.
\end{abstract}

Keywords: private provision of public goods, Cournot-Nash equilibria, Shibata-Warr neutrality.

JEL Code: D3, H4.

Wolfgang Buchholz

Department of Economics

University of Regensburg

93040 Regensburg

Germany

wolfgang.buchholz@wiwi.uni-regensburg.de
Richards Cornes

School of Economics

University of Nottingham

Nottingham NG7 2RD

United Kingdom

richard.cornes@nottingham.ac.uk

Wolfgang Peters

Department of Economics

European University Viadrina

15230 Frankfurt (Oder)

Germany

peters@euv-frankfurt-o.de 


\section{Introduction}

The theory of private provision of a public good typically focuses on interior Cournot-Nash equilibria in which all agents make a strictly positive contribution to the public good. It is, however, well known that such interior solutions are not the only possible outcome of the Cournot-Nash provision game. Rather, corner solutions may occur in which some agents are complete free riders who do not contribute at all to the public good. Whether an interior or corner solution will prevail as a Cournot-Nash equilibrium is largely determined by the distribution of initial income, the preferences of the agents, as well as by the size of the economy. So it has been shown that corner solutions are more likely when incomes or preferences are heterogeneous (see Bergstrom et al., 1986) and the number of agents is high (see Andreoni, 1988). In this paper we will analyse how these determinants interact. In order to simplify the exposition and to emphasise the relationship with the famous Shibata-Warr neutrality (see Shibata, 1971, Warr, 1983, and Cornes and Sandler, 1996) we will concentrate the analysis on economies in which individuals have identical preferences. We first derive a simple general formula that indicates the proportion of all possible income distributions for which an interior Cournot-Nash equilibrium will result. We then apply this formula to generate numerical simulations when the preferences are Cobb-Douglas. It turns out that the likelihood of interior Cournot-Nash equilibria falls dramatically as the number of individuals is increased. When e. g. the private and the public good have equal weight in the utility function interior CournotNash equilibria will almost certainly not arise even if there are only five or six individuals. We conclude by discussing the adverse consequences that this observation might have for Shibata-Warr neutrality.

\section{The Range of Income Distributions Leading to Interior Cournot-Nash equilibrium: General Analysis}

Let $u\left(x_{i}, G\right)$ be the common utility function where $x_{i}$ is private consumption of individual $i$ and $G$ the provision level of a pure public good. Utility is strictly quasi-concave, twice continuously differentiable and strictly monotone increasing in both variables. Additionally we assume that both goods are strictly normal. All individuals have the same linear technology for producing the public good. Without loss of generality the marginal rate of transformation 
between the private and the public good then can be normalised to one. We want to consider economies of different population sizes, denoted by $n$. The average (per person) private good endowment $\bar{y}$, however, is always the same.

Let $e(G)$ be the income expansion path which connects all points in the $x_{i}$-G-space in which the marginal rate of substitution between the public and the private good is equal to one. It follows from strict normality that $e(G)$ is well defined and strictly increasing in $G$, and that $e(0)=0$ holds. The inverse function of $e(G)$ then exists and is denoted by $G\left(x_{i}\right)$.

In order to characterise Cournot-Nash equilibria in an easy way, we will use functions $r\left(G, y_{i}\right)$ which, for any $\left(G, y_{i}\right)$ describes how much an individual with endowment $y_{i}$ would voluntarily contribute to the public good in a Cournot-Nash equilibrium in which aggregate public good supply were $G$. Formally, these "replacement functions" are given by

$$
r\left(G, y_{i}\right)=\max \left(y_{i}-e(G), 0\right) .
$$

By strict normality such a function is strictly monotone decreasing if $G<G\left(y_{i}\right)$ and truncated at $G=G\left(y_{i}\right)$. Note that in the case $G<G\left(y_{i}\right)$ an individual with income $y_{i}$ can only be in a Cournot-Nash equilibrium when her position is on the income expansion path and she makes a strictly positive contribution to the public good. In the case $G \geq G\left(y_{i}\right)$, however, she has no incentive to make a positive contribution to the public good by her own when the other individuals provide $G$. Many other fruitful applications of the replacement function can be found in Cornes and Hartley (2003).

For any distribution $\left(y_{1}, \ldots, y_{n}\right)$ of aggregate initial income among the $n$ agents the public good level $G_{n}^{N}$ in the Cournot-Nash equilibrium then is given by the consistency requirement

(2) $\quad G_{n}^{N}=\sum_{i=1}^{n} r\left(G_{n}^{N}, y_{i}\right)$ 
By $\hat{G}_{n}$ we now denote public good supply which, in an economy consisting of $n$ agents, is obtained when income is equally distributed such that every individual has the same income $\bar{y}$ and makes the same contribution to the public good. Then (2) becomes

(3) $\hat{G}_{n}=n r\left(\hat{G}_{n}, \bar{y}\right)$.

As $\hat{G}_{n}>0$ this Cournot-Nash equilibrium obviously is an interior one where each individual makes a strictly positive contribution to the public good. From Shibata-Warr neutrality it is well known that $\hat{G}_{n}$ also describes public good supply in any interior Cournot-Nash equilibrium, independent of the distribution of aggregate initial income leading to an interior solution. Then $\hat{x}_{n}:=e\left(\hat{G}_{n}\right)$ gives each individual's private consumption not only in the symmetric case but also in any interior Cournot-Nash equilibrium. Now it is possible to describe the set of all income distribution leading to an interior Cournot-Nash equilibrium.

Proposition 1: Given a certain distribution $\left(y_{1}, \ldots, y_{n}\right)$ of aggregate income $n \bar{y}$ the corresponding Cournot-Nash equilibrium is interior if and only if $y_{i}>\tilde{y}_{n}:=\hat{x}_{n}$ for every individual $i=1, \ldots n$.

Proof: Individual $i$ with income $y_{i}$ makes a strictly positive contribution to the public good if and only if $r\left(\hat{G}_{n}, y_{i}\right)>0$ which (by (1)) is equivalent to $y_{i}>e\left(\hat{G}_{n}\right)=\hat{x}_{n}$.

QED.

At first sight the condition on income distributions for having interior Cournot-Nash equilibria provided by Proposition 1 might seem rather innocuous. Nevertheless it implies that the range of income distributions leading to interior Cournot-Nash equilibria shrinks rapidly as $n$ increases. This will turn out to be a consequence of the following result:

Proposition 2: In a public goods economy with population size $n$ the proportion of all income distributions leading to an interior Cournot-Nash equilibrium is 


$$
p_{n}:=\left(\frac{\tilde{g}_{n}}{\bar{y}}\right)^{n-1}
$$

where $\tilde{g}_{n}:=\hat{G}_{n} / n$ is the average contribution in an interior Cournot-Nash equilibrium.

Proof: In the $R^{n}$-space all feasible income distributions are described by the $(n-1)$ dimensional simplex $P_{n}(0)$ the vertices of which are given by the $n$ vectors $(\bar{y}, 0, \ldots, 0)$, $(0, \bar{y}, 0, \ldots, 0), \ldots$ and $(0, \ldots, 0, \bar{y})$. The set of all income distributions $\left(y_{1}, \ldots, y_{n}\right)$ for which $y_{i}>\tilde{y}_{n}$ holds for every $i=1, \ldots, n$ is the interior of the $(n-1)$-dimensional sub-simplex $P_{n}\left(\tilde{y}_{n}\right)$ which has the $n$ vertices $\left(\tilde{z}_{n}, \tilde{y}_{n}, \ldots, \tilde{y}_{n}\right),\left(\tilde{y}_{n}, \tilde{z}_{n}, \tilde{y}_{n}, \ldots, \tilde{y}_{n}\right), \ldots$ and $\left(\tilde{y}_{n}, \tilde{y}_{n}, \ldots, \tilde{y}_{n}, \tilde{z}_{n}\right)$ where $\tilde{z}_{n}:=n \bar{y}-(n-1) \tilde{y}_{n}$. The sub-simplex $P_{n}(\tilde{y})$ is obtained from $P_{n}(0)$ by a linear contraction with the point $(\bar{y}, \ldots, \bar{y})$ as the centroid and $1-\frac{\tilde{y}_{n}}{y}$ as the contraction factor. As it follows from $\tilde{g}_{n}=\hat{G}_{n} / n=\bar{y}-\tilde{y}_{n}$ that $\frac{\tilde{g}_{n}}{\bar{y}}=1-\frac{\tilde{y}_{n}}{\bar{y}}$ the volume of $P_{n}\left(\tilde{y}_{n}\right)$ in the $(n-1)$ dimensional space then is $\left(\frac{\tilde{g}_{n}}{\bar{y}}\right)^{n-1}$ times the volume of $P_{n}(0)$ which gives (4).

QED.

In Figure 1 the idea lying behind the proof of Proposition 2 is illustrated for $n=3$, where the height of the triangle $A B C$ is $\bar{y}$.

\section{Figure 1}

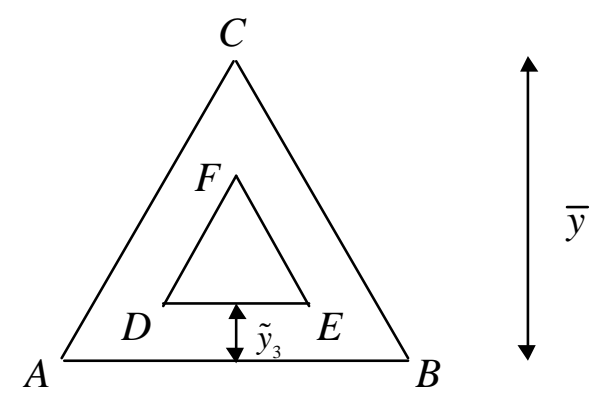


In Figure 1 every point in the equilateral triangle $A B C$ (which has been projected from the three-dimensional into the two-dimensional space) represents a certain income distribution where the income levels of the three agents are given by the vertical distances to the sides of the triangle. The equilateral sub-triangle $D E F$ then represents the set of income distributions which according to Proposition 1 imply an interior Cournot-Nash equilibrium. The normalised side length of $D E F$ is $\frac{\tilde{g}_{3}}{\bar{y}}=1-\frac{\tilde{y}_{3}}{\bar{y}}$ times the side length of the original triangle such that $\left(\frac{\tilde{g}_{3}}{\bar{y}}\right)^{2}$ is the ratio of the areas of both triangles.

The basic formula described by Proposition 1 now makes it possible to describe how $p_{n}$ evolves when $n$ is increased.

Proposition 3: The proportion $p_{n}$ of income distributions leading to an interior CournotNash equilibrium converges to zero when population size goes to infinity.

Proof: By (3) and (4)

$$
\tilde{g}_{n}=r\left(n \tilde{g}_{n}, \bar{y}\right)
$$

holds for any $n$. As the replacement function is strictly decreasing when $G<G(\bar{y})$ and $\hat{G}_{n}<G(\bar{y})$ for any $n$ it follows from (5) that $\tilde{g}_{n}$ is decreasing in $n$. Then it is implied by (4) that $p_{n}$ is bounded from above by $p_{2}^{n-1}=\left(\frac{\tilde{g}_{2}}{\bar{y}}\right)^{n-1}$ which converges to zero as $p_{2}<1$.

\section{QED.}

When preferences for the public good as expressed by the utility function $u$ are strong, then $\tilde{g}_{n}$ will be large. Then, by (4), the share parameter $p_{n}$ will be relatively high for every $n$, too, but $p_{n}$ will nevertheless converge to zero when $n$ grows. Conversely, when preferences for the public good are weak the share parameter will be low, too, and the proportion of income distributions will fall as $n$ rises. 


\section{A Numerical Simulation for the Cobb-Douglas Case}

We now illustrate these results using a specific numerical example. Let individual preferences be described by the general Cobb-Douglas utility function $u\left(x_{i}, G\right)=x_{i}^{\rho} G$ where $\rho>0$. The income expansion path $e(G)$ then is given by $e(G)=\rho G$. Then - by calculating the replacement function in this case and then applying condition (3)

$$
\tilde{G}_{n}=\frac{n \bar{y}}{1+n \rho}
$$

and

$$
\tilde{g}_{n}=\frac{\bar{y}}{1+n \rho}
$$

is obtained for every $n \geq 2$. Then it immediately follows from formula (4) of Proposition 2 that

$$
p_{n}(\rho)=\left(\frac{1}{1+n \rho}\right)^{n-1}
$$

holds for any $n$ and every average endowment level $\bar{y}$. A calculation of $p_{n}(\rho)$ for certain preference parameters $\rho$ and different numbers of individuals $n$ gives the following table:

\section{Table 1}

\begin{tabular}{|c|c|c|c|c|c|c|c|c|c|}
\hline & 2 & 3 & 4 & 5 & 6 & 7 & 8 & 9 & 10 \\
\hline$\rho=0.1$ & $9.17 \cdot 10^{-1}$ & $5.88 \cdot 10^{-1}$ & $3.64 \cdot 10^{-1}$ & $1.97 \cdot 10^{-1}$ & $9.32 \cdot 10^{-2}$ & $4.17 \cdot 10^{-2}$ & $1.63 \cdot 10^{-2}$ & $5.88 \cdot 10^{-3}$ & $1.95 \cdot 10^{-3}$ \\
\hline$\rho=1$ & $3.33 \cdot 10^{-1}$ & $6.25 \cdot 10^{-2}$ & $8.0010^{-3}$ & $7.71 \cdot 10^{-4}$ & $5.94 \cdot 10^{-5}$ & $3.82 \cdot 10^{-6}$ & $2.09 \cdot 10^{-7}$ & $1.00 \cdot 10^{-8}$ & $4.24 \cdot 10^{-10}$ \\
\hline$\rho=2$ & $2.0010^{-1}$ & $2.04 \cdot 10^{-2}$ & $1.37 \cdot 10^{-3}$ & $6.83 \cdot 10^{-5}$ & $2.69 \cdot 10^{-6}$ & $8.77 \cdot 10^{-8}$ & $2.44 \cdot 10^{-9}$ & $5.89 \cdot 10^{-11}$ & $1.26 \cdot 10^{-12}$ \\
\hline
\end{tabular}


As $\rho<1$ is not plausible you would need - figuratively speaking - an "electron microscope" to detect interior Cournot-Nash equilibria even if the economy is not very large.

How small the domain of income distribution leading to interior Cournot-Nash equilibria really is also becomes obvious when we compare the proportion $p_{n}$ with the proportion of income distributions that imply standalone Cournot-Nash equilibria in which only a single individual makes a strictly positive contribution to the public good. Here, we restrict our considerations to the case $\rho=1$, and we assume that individual 1 is to be the sole contributor.

If $y_{1}>\frac{2}{3} n \bar{y}$ holds for a certain income distribution $\left(y_{1}, \ldots, y_{n}\right)$ then it is implied that only individual 1 will make a strictly positive contribution to the public good. Therefore the $(n-1)$ dimensional simplex with the vertices $(n \bar{y}, 0,0, \ldots, 0), \quad\left(\frac{2}{3} n \bar{y}, \frac{1}{3} n \bar{y}, 0, \ldots, 0\right)$, $\left(\frac{2}{3} n \bar{y}, 0, \frac{1}{3} n \bar{y}, 0, \ldots, 0\right), \ldots$ and $\left(\frac{2}{3} n \bar{y}, 0, \ldots, 0, \frac{1}{3} n \bar{y}\right)$ describes a subset of income distributions for which the Cournot-Nash equilibrium has individual 1 as only contributor. This simplex is obtained from the original simplex $P_{n}(0)$ by a contraction for which $(n \bar{y}, 0, \ldots, 0)$ is the centroid and $\frac{1}{3}$ is the contraction factor. In Figure 2 this is described for the case $n=3$ where for all income distributions lying in $G H C$ individual 1 is the sole contributor.

\section{Figure 2}

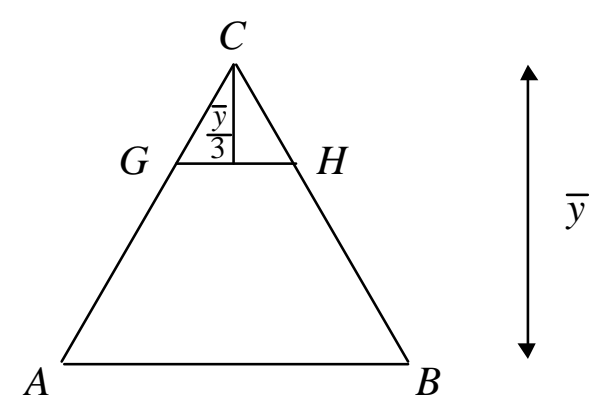


Thus, the proportion $m_{n}^{1}$ of income distributions leading to a standalone Cournot-Nash equilibrium of individual 1 is bounded from above by $\left(\frac{1}{3}\right)^{n-1}$ which implies for $\rho=1$

$$
\frac{m_{n}^{1}}{p_{n}} \leq\left(\frac{n+1}{3}\right)^{n-1}
$$

which is evaluated for $n=2, \ldots, 10$ in the following Table 2 .

\section{Table 2}

\begin{tabular}{|c|c|c|c|c|c|c|c|c|c|}
\hline$n=2$ & 2 & 3 & 4 & 5 & 6 & 7 & 8 & 9 & 10 \\
\hline$m_{n}^{1} / p_{n}$ & 1 & 1.77 & 4.63 & 16.00 & 69.16 & 359.59 & 2187 & 15242 & 119796 \\
\hline
\end{tabular}

This result has the following disturbing consequence. When there are random choices of an income distribution from the set of all income distributions the chance that we will get an income distribution leading to a Cournot-Nash equilibrium with individual 1 as sole contributor is more than 100,000 as large as the chance for obtaining an income distribution for which the Cournot-Nash equilibrium is an interior one when population size is only $n=10$.

Let $m_{n}$ denote the proportion of income distributions for which some individual is the only contributor in an $n$ person economy. Then obviously, $m_{n}=n m_{n}^{1}$ and, e. g., in the case $n=10$ we obtain $m_{10} / p_{10}>10^{6}$. This means that in an economy consisting of only 10 individuals with a relatively high preference for the public good, standalone equilibria will occur, by a random choice of the income distribution, more than 1 million times as often than an interior Cournot-Nash equilibrium. 


\section{Conclusion}

Shibata-Warr neutrality is one of the most striking results in the theory of public goods. In its most elaborate form Shibata-Warr neutrality means that a redistribution of initial income will not change the Cournot-Nash equilibrium supply of the public good when neither the group of contributors nor their aggregate income is changed. One consequence of the result of this paper is that the range of redistribution for which this invariance theorem holds is very $\mathbf{e}$ stricted: Starting from a certain given income distribution the formula contained in Proposition 2 can be used to describe which proportion the redistributions of income leading to Shibata-Warr neutrality have in all income distributions among current contributors. The CobbDouglas example then shows that this proportion will, under not very extraordinary assumptions, become very small even if the number of contributors is not very high. If we compare the proportion of income redistributions for which Shibata-Warr neutrality applies with all possible income distributions (including also some redistribution between contributors and non-contributors) even a much lower share will be obtained. This makes it evident that normally Shibata-Warr neutrality can only be expected when the redistribution of income is of an extremely limited extent. 


\section{References}

Andreoni, J.: Privately provided public goods in a large economy: the limits of altruism. Journal of Public Economics 35, 57 - 73 (1988)

Bergstrom, T. C., Blume, L., Varian, H. R.: On the private provision of public goods. Journal of Public Economics 29, 25-49 (1986)

Cornes, R. C., Hartley, R.: Aggregative public good games. Working Paper: University of Nottingham 2003

Cornes, R., Sandler, T.: The theory of externalities, public goods and club goods, $2^{\text {nd }}$ ed. Cambridge, UK: Cambridge University Press 1996

Shibata, H.: A bargaining model of the pure theory of public expenditure. Journal of Political Economy 79, 1-29 (1971)

Warr, P.: The private provision of a public good is independent of the distribution of income. Economic Letters 13, 207-211 (1983) 


\title{
CESifo Working Paper Series
}

\author{
(for full list see www.cesifo.de)
}

917 Jan C. van Ours, Has the Dutch Miracle Come to an End?, April 2003

918 Bertil Holmlund, The Rise and Fall of Swedish Unemployment, April 2003

919 Bernd Huber and Marco Runkel, Optimal Design of Intergovernmental Grants under Asymmetric Information, April 2003

920 Klaus Wälde, Endogenous Business Cycles and Growth, April 2003

921 Ramon Castillo and Stergios Skaperdas, All in the Family or Public? Law and Appropriative Costs as Determinants of Ownership Structure, April 2003

922 Peter Fredriksson and Bertil Holmlund, Improving Incentives in Unemployment Insurance: A Review of Recent Research, April 2003

923 Bernard M.S. van Praag and Adam S. Booij, Risk Aversion and the Subjective Time Discount Rate: A Joint Approach, April 2003

924 Yin-Wong Cheung, Kon S. Lai, and Michael Bergman, Dissecting the PPP Puzzle: The Unconventional Roles of Nominal Exchange Rate and Price Adjustment, April 2003

925 Ugo Trivellato and Anna Giraldo, Assessing the 'Choosiness' of Job Seekers. An Exploratory Approach and Evidence for Italy, April 2003

926 Rudi Dornbusch and Stanley Fischer, International Financial Crises, April 2003

927 David-Jan Jansen and Jakob de Haan, Statements of ECB Officials and their Effect on the Level and Volatility of the Euro-Dollar Exchange Rate, April 2003

928 Mario Jametti and Thomas von Ungern-Sternberg, Assessing the Efficiency of an Insurance Provider - A Measurement Error Approach, April 2003

929 Paolo M. Panteghini and Guttorm Schjelderup, Competing for Foreign Direct Investments: A Real Options Approach, April 2003

930 Ansgar Belke, Rainer Fehn, and Neil Foster, Does Venture Capital Investment Spur Employment Growth?, April 2003

931 Assar Lindbeck, Sten Nyberg, and Jörgen W. Weibull, Social Norms and Welfare State Dynamics, April 2003

932 Myrna Wooders and Ben Zissimos, Hotelling Tax Competition, April 2003 
933 Torben M. Andersen, From Excess to Shortage - Recent Developments in the Danish Labour Market, April 2003

934 Paolo M. Panteghini and Carlo Scarpa, Irreversible Investments and Regulatory Risk, April 2003

935 Henrik Jacobsen Kleven and Claus Thustrup Kreiner, The Marginal Cost of Public Funds in OECD Countries. Hours of Work Versus Labor Force Participation, April 2003

936 Klaus Adam, George W. Evans, and Seppo Honkapohja, Are Stationary Hyperinflation Paths Learnable?, April 2003

937 Ulrich Hange, Education Policy and Mobility: Some Basic Results, May 2003

938 Sören Blomquist and Vidar Christiansen, Is there a Case for Public Provision of Private Goods if Preferences are Heterogeneous? An Example with Day Care, May 2003

939 Hendrik Jürges, Kerstin Schneider, and Felix Büchel, The Effect of Central Exit Examinations on Student Achievement: Quasi-experimental Evidence from TIMSS Germany, May 2003

940 Samuel Bentolila and Juan F. Jimeno, Spanish Unemployment: The End of the Wild Ride?, May 2003

941 Thorsten Bayindir-Upmann and Anke Gerber, The Kalai-Smorodinsky Solution in Labor-Market Negotiations, May 2003

942 Ronnie Schöb, Workfare and Trade Unions: Labor Market Repercussions of Welfare Reform, May 2003

943 Marko Köthenbürger, Tax Competition in a Fiscal Union with Decentralized Leadership, May 2003

944 Albert Banal-Estañol, Inés Macho-Stadler, and Jo Seldeslachts, Mergers, Investment Decisions and Internal Organisation, May 2003

945 Kaniska Dam and David Pérez-Castrillo, The Principal-Agent Matching Market, May 2003

946 Ronnie Schöb, The Double Dividend Hypothesis of Environmental Taxes: A Survey, May 2003

947 Erkki Koskela and Mikko Puhakka, Stabilizing Competitive Cycles with Distortionary Taxation, May 2003

948 Steffen Huck and Kai A. Konrad, Strategic Trade Policy and Merger Profitability, May 2003

949 Frederick van der Ploeg, Beyond the Dogma of the Fixed Book Price Agreement, May 2003 
950 Thomas Eichner and Rüdiger Pethig, A Microfoundation of Predator-Prey Dynamics, May 2003

951 Burkhard Heer and Bernd Süssmuth, Cold Progression and its Effects on Income Distribution, May 2003

952 Yu-Fu Chen and Michael Funke, Labour Demand in Germany: An Assessment of NonWage Labour Costs, May 2003

953 Hans Gersbach and Hans Haller, Competitive Markets, Collective Decisions and Group Formation, May 2003

954 Armin Falk, Urs Fischbacher, and Simon Gächter, Living in Two Neighborhoods Social Interactions in the LAB, May 2003

955 Margarita Katsimi, Training, Job Security and Incentive Wages, May 2003

956 Clemens Fuest, Bernd Huber, and Jack Mintz, Capital Mobility and Tax Competition: A Survey, May 2003

957 Edward Castronova, The Price of 'Man' and 'Woman': A Hedonic Pricing Model of Avatar Attributes in a Synthetic World, June 2003

958 Laura Bottazzi and Marco Da Rin, Financing Entrepreneurial Firms in Europe: Facts, Issues, and Research Agenda, June 2003

959 Bruno S. Frey and Matthias Benz, Being Independent is a Great Thing: Subjective Evaluations of Self-Employment and Hierarchy, June 2003

960 Aaron Tornell and Frank Westermann, Credit Market Imperfections in Middle Income Countries, June 2003

961 Hans-Werner Sinn and Wolfgang Ochel, Social Union, Convergence and Migration, June 2003

962 Michael P. Devereux, Measuring Taxes on Income from Capital, June 2003

963 Jakob de Haan, Jan-Egbert Sturm and Bjørn Volkerink, How to Measure the Tax Burden on Labour at the Macro-Level?, June 2003

964 Harry Grubert, The Tax Burden on Cross-Border Investment: Company Strategies and Country Responses, June 2003

965 Kirk A. Collins and James B. Davies, Measuring Effective Tax Rates on Human Capital: Methodology and an Application to Canada, June 2003

966 W. Steven Clark, Using Micro-Data to Assess Average Tax Rates, June 2003

967 Christopher Heady, The 'Taxing Wages' Approach to Measuring the Tax Burden on Labour, June 2003 
968 Michael P. Devereux and Alexander Klemm, Measuring Taxes on Income from Capital: Evidence from the UK, June 2003

969 Bernhard Eckwert and Itzhak Zilcha, The Effect of Better Information on Income Inequality, June 2003

970 Hartmut Egger and Josef Falkinger, The Role of Public Infrastructure for Firm Location and International Outsourcing, June 2003

971 Dag Morten Dalen and Trond E. Olsen, Regulatory Competition and Multi-national Banking, June 2003

972 Matthias Wrede, Tax Deductibility of Commuting Expenses and Residential Land Use with more than one Center, June 2003

973 Alessandro Cigno and Annalisa Luporini, Scholarships or Student Loans? Subsidizing Higher Education in the Presence of Moral Hazard, June 2003

974 Chang Woon Nam, Andrea Gebauer and Rüdiger Parsche, Is the Completion of EU Single Market Hindered by VAT Evasion?, June 2003

975 Michael Braulke and Giacomo Corneo, Capital Taxation May Survive in Open Economies, July 2003

976 Assar Lindbeck, An Essay on Welfare State Dynamics, July 2003

977 Henrik Jordahl and Luca Micheletto, Optimal Utilitarian Taxation and Horizontal Equity, July 2003

978 Martin D. D. Evans and Richard K. Lyons, Are Different-Currency Assets Imperfect Substitutes?, July 2003

979 Thorsten Bayindir-Upmann and Frank Stähler, Market Entry Regulation and International Competition, July 2003

980 Vivek Ghosal, Firm and Establishment Volatility: The Role of Sunk Costs, Profit Uncertainty and Technological Change, July 2003

981 Christopher A. Pissarides, Unemployment in Britain: A European Success Story, July 2003

982 Wolfgang Buchholz, Richard Cornes, and Wolfgang Peters, On the Frequency of Interior Cournot-Nash Equilibria in a Public Good Economy, July 2003 